\title{
Microorganisms in Soils of Bovine Production Systems in Tropical Lowlands and Tropical Highlands in the Department of Antioquia, Colombia
}

\author{
Licet Paola Molina-Guzmán, ${ }^{1,2}$ Paula Andrea Henao-Jaramillo, ${ }^{1}$ \\ Lina Andrea Gutiérrez-Builes, ${ }^{1}$ and Leonardo Alberto Ríos-Osorio $\mathbb{D}^{2}$ \\ ${ }^{1}$ Grupo Biología de Sistemas, Facultad de Medicina, Universidad Pontificia Bolivariana, Calle 78B No. 72A-109, Medellín, Colombia \\ ${ }^{2}$ Grupo de Investigación Salud y Sostenibilidad, Escuela de Microbiología, Universidad de Antioquia, \\ Calle 67 No. 53-108, Medellín, Colombia
}

Correspondence should be addressed to Leonardo Alberto Ríos-Osorio; leonardo.rios@udea.edu.co

Received 12 December 2017; Revised 12 February 2018; Accepted 19 February 2018; Published 21 March 2018

Academic Editor: Glaciela Kaschuk

Copyright (C) 2018 Licet Paola Molina-Guzmán et al. This is an open access article distributed under the Creative Commons Attribution License, which permits unrestricted use, distribution, and reproduction in any medium, provided the original work is properly cited.

\begin{abstract}
Studies on the physical and chemical effects of extensive grazing on soils have been performed in Colombia, but the effects of dairy cattle rearing on the biological properties of soils are not well known. The objective of this study was to evaluate microorganisms in 48 soils from livestock farms in the highland and lowland tropics in the Northern and Magdalena Medio subregions of the Department of Antioquia (Colombia). Principal component analysis demonstrated differences in the edaphic compositions of the soils, with increased percentages of root colonization by arbuscular mycorrhizal fungi and the density of microorganisms in farms that have soils with moderate phosphorus and nitrogen contents, low potassium content, and a moderately acidic $\mathrm{pH}$. Agglomerative cluster analysis showed two groups for the highland tropic soils and six groups for the lowland tropic soils based on their population densities and interactions with the studied parameters. These results represent a first attempt to describe the density of microorganisms and the effect of soil physicochemical parameters on colonization by arbuscular mycorrhizal fungi in areas with determinant agroecological conditions, microbial functional diversity, and the presence of mycorrhizal fungi in livestock farm soils in Colombia.
\end{abstract}

\section{Introduction}

Livestock production is the most widespread economic activity worldwide, with one-third of terrestrial land destined for pasture and animal feed cultivation, and uses approximately eight percent of the global freshwater. One of the largest environmental impacts of this activity is the emission of greenhouse gas. An estimated 7.1 billion tonnes of carbon dioxide-equivalent were generated in 2005 by livestock production activities, representing approximately 14 percent of the total human emissions that year contributing to erosion caused by wind and water. This process is associated with compaction and increased apparent density of soils, changes in humidity and $\mathrm{pH}$ depending on the grazing intensity, loss and mineralization of nutrients, and increased decomposition of organic matter due to the breakdown of soil aggregates by trampling [1].

The effects of grazing on soils are reflected in their physical, chemical, and biological properties since this activity contributes to changes in the enzymatic activity and the microflora and macroflora [1]. Microorganisms that are part of the soil microflora are essential to its ecosystemic function since they are involved in processes that regulate biogeochemical cycles, make nutrients available for plant growth, control pathogens, improve the soil structure, and decompose organic matter [2].

Previous studies reported that grazing might also have positive effects on soil species richness, because the decay 
of animal faeces and urine facilitates the diversification of these organisms and their substrates. Grass cutting has been reported to increase activity in the rhizosphere, and trampling can help disperse microbial communities [3]. However, this same phenomenon may negatively affect certain microbial functional groups, such as phosphate-solubilizing microorganisms [4]. Despite the existing studies on the subject, the effects of grazing on the density and diversity of microorganisms are not generalizable since the environmental conditions, type of soil and its properties, type of plant cover, grazing intensity, type of animal, and management practices also have significant influences over the microbial communities [4].

In Colombia, there are two main systems of livestock production: tropical highland and tropical lowland. The former includes systems specialized in dairy production and is characterized by proximity to urban zones and colder climates with an undulating topography, whereas the lowland tropics include double-purpose cattle and are characterized by high temperatures, remoteness of markets, and flat topography. Both production systems present between 80 and $90 \%$ pasture, with a predominance of Pennisetum clandestinum in the highland tropics and Brachiaria spp. in the lowland tropics. These systems present only approximately $10 \%$ forested areas. These systems are also radically different in their soil fertilization processes; in highland tropics with dairy production cattle, pastures are irrigated and fertilized with chemicals and receive large amounts of nitrogen, whereas these processes are rarely performed in the lowland tropics [5].

Although livestock production is becoming more specialized in Colombia, these techniques have been practiced extensively, and activities such as overgrazing, burning, and mechanization have contributed to soil erosion, loss of biodiversity, and decreases in productivity [6]. The physical and chemical properties of the soil in areas destined for beef were studied by Jiménez et al. [7], but the biological components were not evaluated. Cañón-Cortázar et al. [8] reported the density and diversity of microorganisms associated with the nitrogen cycle in soils in paramo plateaus used for doublepurpose livestock (mainly dairy production) combined with potato cultivation. The authors found that livestock might favour the density of these microorganisms due to the use of fertilizers in this production system, the mechanical action on the soil, and the deposition of faecal matter and urine. These studies have focused their analyses on microbial communities in the soils of production systems with agroforestry and intensive silvopastoral systems and have demonstrated that microbial populations of fungi and bacteria are favoured [9] and that the microbial communities generally tend to be similar to the communities found in native forests [10].

Since studies that reflect the impact of livestock on the microbiological properties of soils are scarce, the objective of the present study was to evaluate microorganisms involved in the carbon, nitrogen, and phosphorus cycles in soils used for bovine production systems in tropical lowlands and tropical highlands in the Department of Antioquia, Colombia, offering support to future investigations directed at evaluating their quality and encouraging good management practices to take advantage of this resource. These results represent a first attempt to describe the density of microorganisms and the effect of soil physicochemical parameters on colonization by arbuscular mycorrhizal fungi in areas with determinant agroecological conditions, microbial functional diversity, and the presence of mycorrhizal fungi in livestock farm soils in Colombia.

\section{Materials and Methods}

2.1. Description of the Area and Study Type. An absolute experimental study was performed by comparative observation in two subregions of Antioquia, Colombia. The first group in the northern subregion included the municipalities of Entrerríos, Belmira, and San Pedro de los Milagros, situated between 2,300 and 2,475 metres above sea level with average temperatures between 14 and $16^{\circ} \mathrm{C}$. The second group in the Magdalena Medio subregion included the municipalities of Puerto Berrio, Puerto Triunfo, and Puerto Nare, located between 140 and 125 metres above sea level with an average temperature of $28^{\circ} \mathrm{C}$. A survey was designed as an instrument for the collection of farm information, including general information on the production system and aspects related to the use of fertilizers in the soil.

2.2. Soil Sample Collection. A zigzag track was drawn on the delimited terrain; and subsamples were taken at each vertex where the direction of the course changed. One soil sample was collected for each sampling unit; this sample consisted of a "composite sample" composed of ten subsamples taken at random in the field. At each sampling site, plants and fresh leaf litter were removed $(1-2 \mathrm{~cm})$ from a $40 \mathrm{~cm} \times 40 \mathrm{~cm}$ area, and the soil was extracted to a $20 \mathrm{~cm}$ depth. Approximately $200 \mathrm{~g}$ of soil was transferred to a recipient to remove gravel, thick roots, worms, and insects. Then, the soil samples were crumbled and mixed manually according to recommendations by the Instituto Colombiano Agropecuario [11]. Finally, one kilogram of sample was transferred to a clean, closed plastic bag marked with the name or number of the farm, the date, and the municipality.

2.3. Microbiological Analysis of the Soils. Microorganisms responsible for the biogeochemical processes that occurred in the soil were evaluated. These groups of microorganisms account for the soil functional diversity and are directly associated with its health and fertility (i.e., cellulolytic, proteolytic, amylolytic, phosphate solubilizers, nitrogen-fixing bacteria with glucose as a carbon source, nitrogen-fixing bacteria with malate as a carbon source, Actinobacteria, total fungi, and heterotrophic bacteria). Isolation of the microorganisms was performed by seeding serial dilutions onto the surface of culture media specific for each group, culture medium for cellulolytic [12], culture medium for amylolytic [13], culture medium for proteolytic [14], PK medium for phosphatesolubilizing bacteria [15], Burk culture medium for fixing bacteria of N2-glucose source of C [16], Nfb culture medium for N2-fixing bacteria-malate $\mathrm{C}$ source [17], and starch-casein agar culture medium for actinomycetes [18]. Ten grams of soil was taken and diluted in $90 \mathrm{~mL}$ of $0.85 \%$ sterile saline solution, stirred vigorously for 20 minutes, and allowed to 
settle; then, $1 \mathrm{~mL}$ of sample was transferred to $9 \mathrm{~mL}$ of saline. This procedure was repeated up to the 10-6 dilution. For seeding, we used the 10-4, 10-5, and 10-6 dilutions, which were stirred, dispersed, and homogenized with $0.1 \mathrm{~mL}$ of sample over the culture medium using a Drigalski bacterial loop. Each dilution was seeded in duplicate and incubated at $28^{\circ} \mathrm{C}$ for the time necessary for the growth of each group of microorganisms as recommended by the same authors [14]. The growth of each group was reported as the colony forming units per gram of dry soil (CFU/gs.s.).

\subsection{Determination of the Percentage of Root Colonization by} Arbuscular Mycorrhizal Fungi (AMF). To evaluate the functioning of the mycorrhizal fungi, the presence of colonization in the roots must be determined and quantified. The percent colonization was determined by staining fungal structures inside the root. The roots were initially discoloured with a strong base $(10 \% \mathrm{KOH})$, neutralized with an acid $(10 \%$ $\mathrm{HCl}$ ), and exposed to $0.05 \%$ Trypan blue for three days. Then, the roots were observed under a microscope (NIKON E200, NY, USA) to determine the presence of arbuscules, vesicles, and endospores. The percentage of root colonization was calculated as described by Phillips and Hayman [19].

2.5. AMF Spore Count. Spores of AMF are considered the most important reproductive structures and are generally the most resistant to adverse conditions compared to other propagules. Spores are also considered a relative indicator of the abundance of the AMF populations. For this determination, $10 \mathrm{~g}$ of soil was added to $20 \mathrm{~mL}$ of $5 \%$ hydrogen peroxide and stirred every three minutes for 15 minutes; then, a preliminary screening with 0.250 and $0.045 \mathrm{~mm}$ sieves was performed, and the spores were extracted by gradient centrifugation for three minutes at $2640 \mathrm{rpm}$ using $80 \%$ sucrose. Three-quarters of the tube contents were deposited onto the $0.045 \mathrm{~mm}$ sieve, washed for three minutes to remove the sucrose, and transferred to filter paper in a Petri dish. The spore count was performed in a stereoscope (NIKON SMZ445, Melville, NY 11747-3064USA), and the results are expressed as the number of spores per gram of soil following the description of García et al. (2012).

2.6. Physical-Chemical Analysis of the Soils. Analysis of the physicochemical properties was performed using professional testing equipment for soil analysis (model STH-14 code 5010-01, LaMotte Company, MD, USA). The nitrate, nitrite, ammoniacal nitrogen, phosphorus, magnesium, and aluminium concentrations were evaluated through colorimetric tests for determination of available minerals and the calcium; this test measures the amount of calcium present in the base exchange complex and available potassium concentrations were evaluated using turbidity tests. The values for all parameters are expressed as $\mathrm{mg} / \mathrm{kg}$ according to the manufacturer's recommendations. Additionally, the moisture content was determined as described in ASTM D4959-07 [20] with some modifications; the amount of soil used was $10 \mathrm{~g}$ per sample, and the drying time was 24 hours.
2.7. Statistical Analysis. Summary measures were calculated for the quantitative variables. The percent variability of the microorganism density, root colonization, and number of AMF spores and the physicochemical parameters of the sampled farms were determined using a multivariate principal component analysis. The classification of the sampled farms, which took into account information collected in the principal component analysis, was performed with an agglomerative cluster analysis of squared Euclidean distances with Ward's method. The normality of the dataset was verified based on the Shapiro-Wilk test to determine the statistical relationships between variables $(p \leq 0.05)$. Subsequently, the Spearman correlation coefficient (rho) and the coefficient of determination $(r 2)$ were estimated in both regions and by region. All statistical analyses were performed in the Statistical Package for the Social Sciences (SPSS) version 22 for Windows XP.

\section{Results and Discussion}

3.1. Management of the Studied Cattle Farms. The predominant pasture in all analysed soils in the northern subregion (highland tropics) was kikuyu (Pennisetum clandestinum). Fertilizer use was a management practice in all evaluated farms; chemical fertilization combined with organic fertilization (52.2\%) predominated, with a frequency of 45 days or less in 12 of the 24 farms (RIC 40-49). The production of organic manure was not a predominant activity in this highland tropic region (16.7\%). Pest control was common in most cattle farms $(91.3 \%)$, with a frequency of 45 days or less in 12 of the 24 farms (RIC 32-45), and the predominant production system was dairy. Regarding soil management in the farms of the Magdalena Medio subregion (lowland tropics), the predominant pasture species were in the genus Brachiaria, especially $B$. decumbens, $B$. humidicola, and B. brizantha, and the main production systems were reproduction and doublepurpose. The farms of the Magdalena Medio subregion, fertilizer use, manure production, and pest control were not reported as management practices.

Several studies have revealed that the application of fertilizers and irrigation play important roles in increasing the production of green fodder. However, the excessive use of fertilizers, such as ammonium sulphate, might change soil conditions, such as the $\mathrm{pH}$ and the populations of some microorganisms [10, 21]. The application of organic materials stimulates the growth of the microbial populations in charge of the nitrification processes by increasing the levels of soluble nutrients for plants, water retention that facilitates nutrient exchange from organic matter, and the solubility of minerals such as potassium [14].

3.2. Population Density of Soil Microorganisms. Regarding the population density of the nine groups of microorganisms in the soils of the farms in this study, the average density of the heterotrophic bacteria $\left(3.0 \times 10^{5} \mathrm{CFU} / \mathrm{g}\right.$ dry soil $)$ in Northern Antioquia was higher than the average density of the farms in the Magdalena Medio subregion (average $1.3 \times 10^{4} \mathrm{CFU} /$ g dry soil). Similar results were obtained when evaluating the densities of the amylolytic bacteria, proteolytic bacteria, 
Actinobacteria, nitrogen-fixing bacteria that use malate as a carbon source, and nitrogen-fixing bacteria that use glucose as a carbon source, with average values of $2.2 \times 10^{5}, 3.0 \times$ $10^{4}, 1.5 \times 10^{4}, 2.0 \times 10^{5}$, and $9.2 \times 10^{5} \mathrm{CFU} / \mathrm{g}$ dry soil in the northern subregion compared with $2.3 \times 10^{3}, 2.2 \times 10^{3}, 2.2 \times$ $10^{3}, 8.3 \times 10^{3}$, and $3.0 \times 10^{3} \mathrm{CFU} / \mathrm{g}$ dry soil obtained in the Magdalena Medio subregion, respectively.

However, the average values obtained for the fungal counts $\left(1.5 \times 10^{6} \mathrm{CFU} / \mathrm{g}\right.$ dry soil) and cellulolytic bacteria (2.0 $\times 10^{5} \mathrm{CFU} / g$ dry soil) were higher in Magdalena Medio than in the northern subregion (average values of $7.1 \times 10^{3}$ and $6.6 \times$ $10^{3} \mathrm{CFU} / \mathrm{g}$ dry soil, resp.). The average densities of phosphatesolubilizing bacteria in both subregions were similar with 2.5 $\times 10^{4}$ and $2.2 \times 10^{4} \mathrm{CFU} / g$ dry soil for the Northern and Magdalena Medio subregions, respectively.

The number of CFUs of these groups in each municipality varied as follows: for the farms located in the northern subregion, specifically in Entrerríos and Belmira, the values obtained for heterotrophic bacteria, proteolytic bacteria, nitrogen-fixing bacteria that use glucose as a carbon source, nitrogen-fixing bacteria that use malate as a carbon source, and Actinobacteria were, on average, $2.6 \times 10^{5}, 5.8 \times 10^{2}, 6.3$ $\times 10^{5}, 5.4 \times 10^{4}$, and $7.5 \times 10^{3} \mathrm{CFU} / \mathrm{g}$ of dry soil, respectively, for both municipalities. These values were lower than the values found in the municipality of San Pedro de los Milagros, with average numbers of $4.0 \times 10^{5}, 6.7 \times 10^{4}, 1.5 \times 10^{6}$, $2.3 \times 10^{5}$, and $3.0 \times 10^{5} \mathrm{CFU} / \mathrm{g}$ of dry soil, respectively. The population behaviour of the cellulolytic bacteria $(5.0 \times$ $10^{3} \mathrm{CFU} / \mathrm{g}$ dry soil) in the municipalities of San Pedro de los Milagros and Entrerríos was lower compared to Belmira $\left(1.2 \times 10^{5} \mathrm{CFU} / \mathrm{g}\right.$ dry soil). The opposite trend was observed for the population density of amylolytic bacteria, with higher numbers found in San Pedro de los Milagros and Entrerríos $\left(3.0 \times 10^{5} \mathrm{CFU} / \mathrm{g}\right.$ dry soil) and lower numbers found in Belmira $\left(9.4 \times 10^{4} \mathrm{CFU} / g\right.$ dry soil). Belmira and San Pedro de los Milagros presented lower average counts of fungi and phosphate-solubilizing bacteria $\left(5.0 \times 10^{4}\right.$ and $4.2 \times$ $10^{2} \mathrm{CFU} / g$ dry soil, resp.) than Entrerríos $\left(1.1 \times 10^{4}\right.$ and 2.2 $\times 10^{4} \mathrm{CFU} / \mathrm{g}$ dry soil, resp.).

For the municipalities in the Magdalena Medio subregion, the numbers of heterotrophic bacteria, cellulolytic bacteria, and Actinobacteria were higher on average in the municipalities of Puerto Berrio and Puerto Nare, with $1.7 \times$ $10^{5}, 3.0 \times 10^{5}$, and $3.3 \times 10^{3} \mathrm{CFU} / \mathrm{g}$ of dry soil, respectively, compared to the population densities obtained in the municipality of Puerto Triunfo, with $5.0 \times 10^{4}, 2.0 \times 10^{4}$, and $1.0 \times$ $10^{1} \mathrm{CFU} / \mathrm{g}$ of dry soil, respectively. The population numbers of the phosphate-solubilizing bacteria, amylolytic bacteria, and proteolytic bacteria were higher in the municipality of Puerto Berrio $\left(3.2 \times 10^{4}, 7.4 \times 10^{4}\right.$, and $6.7 \times 10^{2} \mathrm{CFU} / \mathrm{g}$ of dry soil, resp.) compared to the values obtained for Puerto Triunfo and Puerto Nare $\left(5.0 \times 10^{3}, 7.0 \times 10^{2}\right.$, and $1.0 \times 10^{1}$ of dry soil, resp., for both municipalities). The values obtained for nitrogen-fixing bacteria that use malate as a carbon source were similar for all three municipalities, with an average count of $3.0 \times 10^{4} \mathrm{CFU} / \mathrm{g}$ dry soil. The opposite trend was observed for nitrogen-fixing bacteria that use glycose as a carbon source, with different values obtained for each municipality [the highest in Puerto Berrio $\left(7.3 \times 10^{4} \mathrm{CFU} / \mathrm{g}\right.$ dry soil), followed by Puerto Triunfo $\left(1.4 \times 10^{4} \mathrm{CFU} / \mathrm{g}\right.$ dry soil), and finally, Puerto Nare $\left(3.3 \times 10^{2} \mathrm{CFU} / \mathrm{g}\right.$ dry soil $\left.)\right]$.

Comparing the results obtained in the present study and the values reported in the literature and taking into account the edaphic changes that occurred within each subregion, different strains of bacteria, such as Azospirillum brasilense, showed significant increases in growth and total incorporation of nutrients. Likewise, different strains exposed to different concentrations of fertilizers improved the assimilation of nutrients either by changing the root structure or with the aid of the bacterial enzyme nitrate reductase. However, this effect may be due to the involvement of the plants in symbiotic associations with the bacteria, resulting in the nutrients being obtained by biological fixation [15].

3.3. Percent Root Colonization by AMF and Spore Density. When evaluating the percent root colonization by AMF in the soils of the farms under study, similar average values were obtained for colonization in both the Northern and Magdalena Medio subregions. In the northern subregion municipalities, the highest value for colonization was found in the municipality of Entrerríos (63.4\%), followed by Belmira (48.3\%) and San Pedro de los Milagros (34.2\%). In the Magdalena Medio subregion, the municipality of Puerto Berrio presented the highest colonization rate $(65.5 \%)$, followed by Puerto Nare (48\%) and Puerto Triunfo (43\%).

However, variability was observed within each municipality for each subregion. For farms in the northern subregion in the municipality of Entrerríos, AMF colonization varied between 11 and 91\%, with farms F3 and F5 presenting the highest percent colonization (91 and 90.5\%, resp., which represented a significant difference $(p=0.04)$ compared to farm F6 with 11\%). In the municipality of Belmira, the percent colonization varied between 16.5 and $86 \%$, with farm F9 presenting the highest value of $86 \%$, which represented a significant difference ( $p=0.05)$ compared to farms F14 and F16, with colonization rates of $16.5 \%$. In the municipality of San Pedro de los Milagros, the observed percent colonization varied between 16 and 51\%, with the highest values in farm F20 (51\%) and the lowest in farm F17 (16\%). The results for the farms in this municipality are statistically similar among themselves.

In the Magdalena Medio subregion, colonization by AMF in the municipality of Puerto Berrio was between 38 and $86 \%$, with farms F25 and F31 presenting the highest percent colonization (86 and $83 \%$, resp.); this percent colonization was significantly different $(p=0.03)$ from farm F30, with $38 \%$ colonization. In the municipality of Puerto Triunfo, the percent colonization varied between 4.0 and $80 \%$; the highest values were obtained in farm F38 (80\%) and were significantly different ( $p=0.01$ ) relative to farm F34, with $4.0 \%$ colonization. The lowest percent root colonization values among all municipalities in the study were observed in the municipality of Puerto Nare, where colonization varied between 67 and 4.0\%; farm F44 presented 67\% AMF colonization and farm F48 presented 4\% AMF colonization, which represented a significant difference $(p=0.001)$. 
The highest number of AMF spores was found in the soils of farms in the municipalities in the northern subregion of Antioquia. The values obtained for the municipality of Entrerríos gave an average of 363 spores/g soil, followed by the soils from Belmira and San Pedro de los Milagros, with 216 and 215 spores/g soil, respectively. For the municipalities in the Magdalena Medio subregion, the highest values were obtained from Puerto Triunfo, with 80 spores/g soil, followed by the municipality of Puerto Triunfo, with 56 spores/g soil, and the municipality of Puerto Berrio, with 51 spores/g soil.

The numbers of spores varied among the municipalities in the northern subregion. The values varied between 47 and 683 spores/g of soil for the farms in Entrerríos, with farm F7 presenting the highest density (683 spores/g soil) and a significant difference relative to the other farms $(p=0.045)$. For the municipality of Belmira, these values ranged between 22 and 706 spores/g soil, with the highest density found in farm F11 (706 spores/g soil); this value presented a significant difference $(p=0.03)$ relative to the other farms. For the municipality of San Pedro de los Milagros, the number of spores varied between 67 and 293 spores/g soil, with the highest spore density found in farm F21; this value was significantly different ( $p=0.035$ ) compared to farm F23 (67 spores/g soil).

In the Magdalena Medio subregion, the soils from the municipality of Puerto Berrio presented a density between 29 and 110 spores/g soil, with farm F27 presenting the highest values (110 spores/g soil) and representing a significant difference $(p=0.01)$ compared to the other farms. For the municipality of Puerto Nare, the counts ranged between 26 and 195 spores/g soil; farm F42 presented the highest density, which was significantly different $(p=0.03)$ compared to farm F46 (34 spores/g soil). The soils from the municipality of Puerto Triunfo presented a density between 18 and 97 spores/g soil, with farm F40 presenting the highest values (97 spores/g soil), which was significantly different $(p=0.04$ ) compared to farms F36 and F37 (18 and 20 spores/g soil, resp.).

3.4. Physical and Chemical Properties of the Soils. The humus, nitrite, potassium, aluminium, and ammoniacal nitrogen concentrations were constant in all of the evaluated municipalities (low, $1 \mathrm{mg} / \mathrm{kg}, 50 \mathrm{mg} / \mathrm{kg}, 86 \mathrm{mg} / \mathrm{kg}$, and $5 \mathrm{mg} / \mathrm{kg}$, resp.). The $\mathrm{pH}$ varied from moderately acidic to slightly acidic for the farms located in the northern subregion, whereas the $\mathrm{pH}$ values for the farms in the Magdalena Medio subregion were strongly acidic.

The percent moisture in the soils was higher in the municipalities located in the northern subregion than in the soils located in the Magdalena Medio subregion. The average humidity was $85 \%$ in the soils from San Pedro de los Milagros, $73 \%$ in the soils from Entrerríos, $68 \%$ in the soils from Belmira, 25\% in the soils from Puerto Triunfo, 20\% in the soils from Puerto Nare, and 18\% in the soils from Puerto Berrio.

The nitrate and calcium concentrations were similar among farms located in the same subregion but differed between subregions. The nitrate and calcium concentrations were approximately $13 \mathrm{mg} / \mathrm{kg}$ and $3458 \mathrm{mg} / \mathrm{kg}$ for the northern subregion and $5 \mathrm{mg} / \mathrm{kg}$ and $2791 \mathrm{mg} / \mathrm{kg}$ for Magdalena Medio, respectively. The opposite trend was observed for the average phosphorus and magnesium concentrations, with the farms in the Magdalena Medio subregion presenting higher values $(67 \mathrm{mg} / \mathrm{kg}$ and $30 \mathrm{mg} / \mathrm{kg}$, resp.) compared to the concentrations from the soils from the northern subregion (29 $\mathrm{mg} / \mathrm{kg}$ and $12 \mathrm{mg} / \mathrm{kg}$, resp.).

3.5. Relationships between the Population Density of Microorganisms, Percentage of Root Colonization, Numbers of Spores, and Physicochemical Properties. The principal component analysis of the population densities of microorganisms in livestock farms in the subregion of the north (Figure 1) showed that the first component (" $x$-"axis) contrasted the microorganism population density (cellulolytic, amylolytic, proteolytic, and nitrogen-fixing bacteria that use glucose as a carbon source, fungi, heterotrophic bacteria, and phosphate solubilizers) with the percentage of colonization, with a component value of $\ddot{e}_{1}=6.2$ that explained $62 \%$ of the total variability of the data. Farm F3 presented high numbers of microorganisms, the highest percent colonization values (90\%) and spore counts (509 spores/g soil), and a moderately acidic pH. Farms F34 and F36 presented high phosphorus contents (375 mg/kg), low colonization values (4.1 and 6.3\%, resp.), and lower population densities $\left(6.7 \times 10^{2} \mathrm{CFU} / \mathrm{g}\right.$ dry soil).

The second component (" $y$-"axis) was associated with the population density of fungi, nitrogen-fixing bacteria that used malate as a carbon source, and Actinobacteria, with a component value of $\ddot{e}_{2}=3.0$ that explained $30 \%$ of the total variability of the data. For example, farms F18 and F23 had higher population densities of Actinobacteria $\left(4 \times 10^{5} \mathrm{CFU} /\right.$ $\mathrm{g}$ dry soil) and nitrogen-fixing bacteria that used malate as a carbon source $\left(1.4 \times 10^{6} \mathrm{CFU} / g\right.$ dry soil $)$, high AMF spore counts (683 spores/g soil), and low percentages of root colonization when high phosphorus contents were present $(100 \mathrm{mg} /$ $\mathrm{kg}$ ). Both components explained $92 \%$ of the variation of the data.

The analysis of microorganism population densities compared to the physicochemical parameters by agglomerative cluster analysis (Figure 2) based on the principal component analysis for population densities (Figure 1) for the northern subregion localities showed two groups of farms based on their microorganism counts, percentage of root colonization, and physic chemical parameters of the soil (Figure 2(a)). Group 1 contained farms associated with a moderately acidic $\mathrm{pH}$; low phosphorus, ammoniacal nitrogen, and magnesium concentrations; low counts of heterotrophic bacteria, proteolytic bacteria, and fungi; allowing a percentage of mycorrhizal colonization; and moderate numbers of spores per gram of soil. Group 2 consisted of a farm with a slightly acidic $\mathrm{pH}$; low phosphorus, potassium, and aluminium concentrations; a low ammoniacal nitrogen concentration; high microorganism numbers; and higher percentages of colonization by AMF.

Five groups were formed in the Magdalena Medio subregion (Figure 2(b)). Group 1 presented farms associated with moderate microorganism population densities and similar phosphate, nitrate, aluminium, and calcium concentrations. Group 2 contained farms associated with low phosphate and magnesium concentrations, a moderate calcium concentration, a low percentage of colonization, and low humidity. 


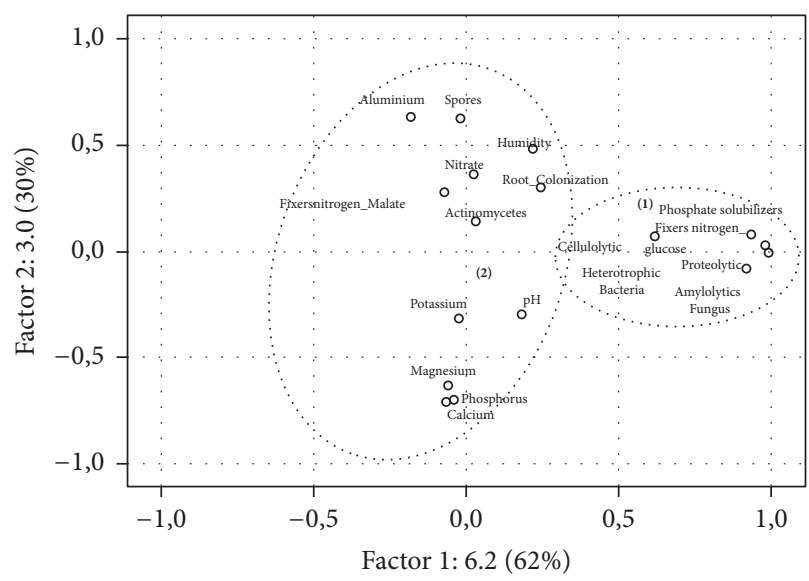

(a)

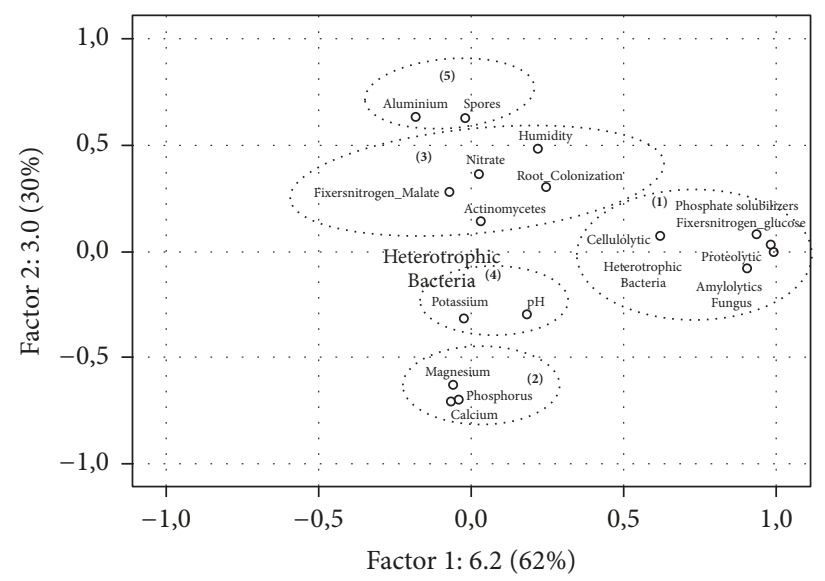

(b)

FIGURE 1: Principal component analysis of the population density of microorganisms, percentage of colonization, and soil physicochemical parameters on the cattle farms under study. (a) (1)-(2): farm groups related to parameters measured in Northern Antioquia (Colombia). (b) (1)-(5): farm groups related to parameters measured in Magdalena Medio Antioquia (Colombia).

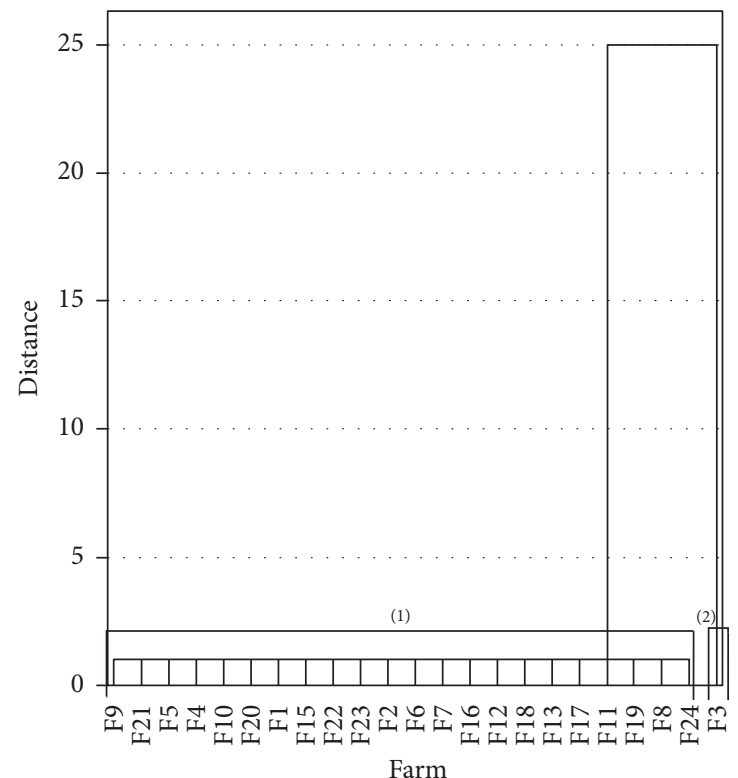

(a)

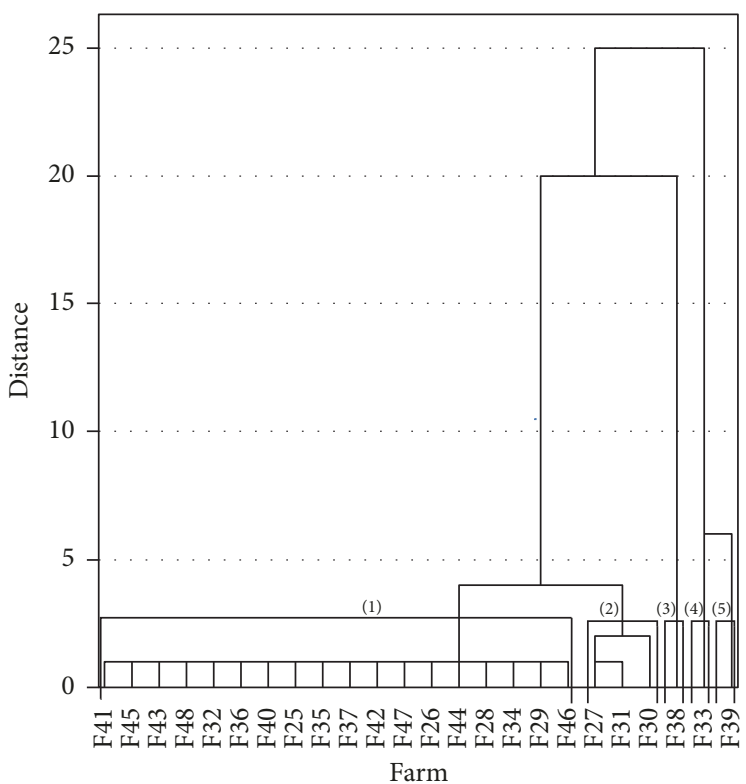

(b)

FIGURE 2: Agglomerative cluster analysis between the microorganism population density, percentage of colonization, and soil physicochemical parameters for cattle farms. (a) (1)-(2): farm groups related to parameters measured in Northern Antioquia (Colombia). (b) (1)-(5): farm groups related to parameters measured in Magdalena Medio, Antioquia (Colombia).

Group 3 consisted of one farm that presented a null density of Actinobacteria, low nitrogen-fixing bacteria that use malate as a carbon source count, a low nitrate concentration, low humidity, a moderate percentage of colonization, and a strongly acidic $\mathrm{pH}$. Group 4 contained one farm that presented moderately acidic $\mathrm{pH}$, low potassium and aluminium concentrations, a low percentage of colonization, and low humidity. Group 5 contained one farm with a high aluminium concentration, high spore count, high fungal population density relative to the other microorganisms, and a strongly acidic $\mathrm{pH}$.
The correlation analysis of the soil chemical parameters indicated that significant differences existed between the macroelements (phosphorus, aluminium, calcium, and nitrate) and humidity evaluated in this study. A positive correlation was observed in both subregions between the humidity and the population densities of proteolytic bacteria, nitrogen-fixing bacteria that use glycose as a carbon source, nitrogen-fixing bacteria that use malate as a carbon source, and Actinobacteria and the density of spores per gram of soil. A positive correlation was also observed with the percentage of root colonization by AMF, the aluminium concentration, 
TABLE 1: Spearman's correlation (Rho) coefficients between physicochemical properties, microorganism, and biological activity of endomycorrhizal fungi in the soil from 48 farms in the North and Magdalena Medio subregions in Antioquia, Colombia.

\begin{tabular}{|c|c|c|c|c|c|c|}
\hline & $\begin{array}{l}\text { Humidity } \\
\text { percentage }\end{array}$ & $\begin{array}{c}\text { Phosphorus } \\
(\mathrm{mg} / \mathrm{kg})\end{array}$ & $\begin{array}{c}\text { Aluminium } \\
(\mathrm{mg} / \mathrm{kg})\end{array}$ & $\begin{array}{l}\text { Calcium } \\
(\mathrm{mg} / \mathrm{kg})\end{array}$ & $\begin{array}{c}\text { Magnesium } \\
(\mathrm{mg} / \mathrm{kg})\end{array}$ & $\begin{array}{l}\text { Nitrate } \\
(\mathrm{mg} / \mathrm{kg})\end{array}$ \\
\hline Spores/g soil & $0.530^{* *}$ & -0.272 & $0.312^{*}$ & $-0.48^{* *}$ & $-0.496^{* *}$ & $0.330^{*}$ \\
\hline $\begin{array}{l}\text { Percentage of root } \\
\text { colonization by AMF }\end{array}$ & -0.208 & $-0.550^{* *}$ & $0.428^{* *}$ & -0.266 & -0.133 & -0.266 \\
\hline Proteolysis & $0.401^{*}$ & 0.055 & -0.187 & -0.048 & $-0.349^{*}$ & $0.444^{* *}$ \\
\hline $\begin{array}{l}\text { Nitrogen-fixing bacteria } \\
\text { glycose as a carbon source }\end{array}$ & $0.363^{*}$ & -0.115 & -0.081 & -0.105 & $-0.427^{* *}$ & 0.280 \\
\hline $\begin{array}{l}\text { Nitrogen-fixing bacteria } \\
\text { malate as a carbon source }\end{array}$ & $0.389^{* *}$ & 0.135 & -0.085 & 0.007 & -0.281 & $0.406^{* *}$ \\
\hline Actinobacteria & $0.404^{* *}$ & 0.111 & -0.074 & 0.186 & -0.222 & $0.437^{* *}$ \\
\hline
\end{tabular}

${ }^{*}$ Correlation is significant at $p=0.05 .{ }^{* *}$ Correlation is significant at $p=0.01$.

and the densities of bacteria, Actinobacteria, and nitrogenfixing bacteria that use malate as a carbon source with the nitrate concentration. Furthermore, the population densities of proteolytic microorganisms and nitrogen-fixing bacteria that use glycose as a carbon source were negatively correlated with the magnesium concentration. The percentage of root colonization by AMF presented a significant negative correlation with the soil phosphorous concentration (Table 1).

The correlation analysis of the soil chemical parameters indicated that significant differences existed between the macroelements by region, for the concentration values of elements such as $\mathrm{Ca}, \mathrm{Mg}, \mathrm{K}$, and $\mathrm{P}$ and $\mathrm{pH}$ obtained in this study and a strong significant negative correlation was found between these parameters and the spore count for the Magdalena subregion; however, in the subregion of the north, the correlation was significant negative for the calcium concentration and for the other parameters evaluated no correlation was found. Additionally, when evaluating the correlation of the parameters with the percentage of colonization, a slight positive correlation was observed with the concentration of phosphorus and potassium in the subregion of the north; for the other parameters evaluated and the subregion of Magdalena Medio, no correlation was found. Regarding the percentage of colonization and the concentration of $\mathrm{K}$ and $\mathrm{P}$ a slight positive correlation was observed in the subregion of north (Table 2).

The influence of $\mathrm{K}$ on the number of spores is probably due to the fact that the concentrations of this element in the soil were high $(50 \mathrm{mg} / \mathrm{kg}$,) for $97.5 \%$ of the sampled farms, which explains that having the soil higher levels of this element decreases the number of spores in the rhizosphere. In the case of $\mathrm{P}$, the greater content in the soil, the lower number of spores in the soil. These data confirm what was obtained by Mofidi et al. [1], where it was determined that increasing the concentration of $\mathrm{P}$ in the soil increases the electrical conductivity and modifies the osmotic potentials that can affect both the diversity and the number of spores (Table 2).

Likewise, when considering the subregion of Magdalena Medio with a ground of low elevation mountains that undergo processes of laminar erosion, subjected to the use in extensive cattle ranching, microbial biomass and respiration index show very low levels. Additionally, very high counts of mycorrhizal spores are possible, since the strongly acidic $\mathrm{pH}$ tends to favour the development of fungi, in this case, the formation of arbuscular mycorrhizae and the production of their reproductive structures [11].

AMF (Glomeromycetes) represent between 5 and $50 \%$ of the total biomass of soil microorganisms [16]. Symbiotic associations with AMF increase nutrient assimilation, especially phosphorus, because the diameter and length of the hyphae allow the plant to explore a larger volume of the edaphic environment. These relationships also allow the formation of micro- and macroaggregates that improve the physical characteristics of the soil $[3,17]$. Additionally, AMF play an important role in the acquisition of nitrogen for the plant; according to Zubek et al. (2012), mycorrhizal fungi have a direct effect on the absorption of nutrients in the symbiotic system formed by the fungus and the plant roots [2].

These associations in ecosystems are influenced by the relationships among organic and inorganic nutrients, hydric relationships, and the carbon cycle in plants, as well as the edaphic conditions, such as the chemical composition, humidity, temperature, $\mathrm{pH}$, cation exchange capacity, and biotic and abiotic factors [22], and can affect plant endosymbiosis and AMF. For instance, an excess temperature can affect the germination of spores and induce moisture deficiency, which can inhibit the formation of endosymbiosis.

The phosphorus concentration favours the structure of the microbial community by significantly increasing the relative abundance of AMF, which obtains carbon from its host plants in exchange for mineral nutrients [23]. Conversely, if the phosphorus availability increases, a decrease in the abundance of AMF is expected [24]. Our results are consistent with the expectation that the abundance of $\mathrm{P}$ suppresses the inversion of the plant in mycorrhizal symbiosis (see Table 1), which was the case in the lowland tropics, whereas adding phosphorus may increase mycorrhizal growth. Because they are more efficient as soil nutrient cleaners than plant roots, the threshold for nutrient limitation may be lower for mycorrhizal fungi than for plants. Another possible explanation is that an increase in the soil $\mathrm{pH}$ is often associated with an increase in the AMF biomass in the soil [25]. 
TABLE 2: Spearman's correlation (Rho) coefficients between the spore counts, the percentage of colonization, and the physical-chemical properties of the soils studied by region.

\begin{tabular}{lcccccccccc}
\hline & \multicolumn{2}{c}{$\mathrm{pH}$} & \multicolumn{2}{c}{$\begin{array}{c}\text { phosphorus } \\
(\mathrm{mg} / \mathrm{kg})\end{array}$} & \multicolumn{2}{c}{$\begin{array}{c}\text { potassium } \\
(\mathrm{mg} / \mathrm{kg})\end{array}$} & \multicolumn{2}{c}{$\begin{array}{c}\text { Calcium } \\
(\mathrm{mg} / \mathrm{kg})\end{array}$} & $\begin{array}{c}\text { Magnesium } \\
(\mathrm{mg} / \mathrm{kg})\end{array}$ \\
\hline $\begin{array}{l}\text { Subregion } \\
\text { Spores/g soil }\end{array}$ & $N$ & $M M$ & $N$ & $M M$ & $N$ & $M M$ & $N$ & $M$ & $\begin{array}{c}M \\
M\end{array}$ \\
$\begin{array}{l}\text { Percentage of root } \\
\text { colonization by AMF }\end{array}$ & $-0.530^{* *}$ & $-0,735^{*}$ & -0.272 & $-0,703^{*}$ & $0.312^{*}$ & $-0,807^{* *}$ & $-0.48^{* *}$ & $-0,659^{*}$ & $0.496^{* *}$ & $-0,715^{*}$ \\
\hline
\end{tabular}

${ }^{*}$ Correlation is significant at $p=0.05 .{ }^{* *}$ Correlation is significant at $p=0.01 . N$ : north subregion (tropical highlands) and MM: Magdalena Medio subregion (tropical lowlands).

\section{Conclusions}

The AMF-plant-microorganism relationship is not considered specific, since any AMF or bacterial species can colonize or form a symbiotic relationship. However, some of these microorganisms may benefit a certain host to a higher or lower degree under certain soil and climate conditions.

Mycorrhizal fungi are a biological resource whose management and conservation effects on plant productivity generate environmental benefits by improving the physicalchemical and biological conditions of the soil. The benefits from a biological perspective derive from their interactions with the various macrogroups and microorganisms of the rhizosphere, such as those involved in the cycling of nutrients (nitrogen-fixing bacteria and phosphate-solubilizing microorganisms). Furthermore, fungi that interact with the microorganisms are involved in the biological control of pathogens present in the soil, demonstrating that different types of interactions exist with arbuscular mycorrhizal fungi. The $\mathrm{pH}$, soil moisture, and nutrient availability influence not only the colonization but also the number of spores produced by AMF. AMF are found in all types of soils and can colonize any plant that establishes symbiosis with them; however, the physical-chemical conditions of the soil could generate some degree of specificity with respect to the host plants based on the responses shown by the plants to certain AMF species.

Few studies have demonstrated the effect of environmental conditions on the establishment of AMF and microbial communities in different ecosystems. This study is one of the first to focus on the highland and lowland tropics of Antioquia, Colombia, and shows certain physic chemical parameters (i.e., $\mathrm{pH}$, phosphorus, nitrogen, and sodium) of soils from livestock farms in the Department of Antioquia that have a direct effect on the establishment of AMF on roots and some soil microorganism groups.

\section{Conflicts of Interest}

The authors declare that there are no conflicts of interest regarding the publication of this paper.

\section{Acknowledgments}

This research was supported by Departamento Administrativo de Ciencia, Tecnología e Innovación (COLCIENCIAS), Grant no. 121056934576; CIDI-UPB no. 211B-02/14-65. The authors acknowledge COLCIENCIAS for the support to
Paula Henao in the National Call for Young Researchers and Innovators 645-2014 (Convention no. 0208-2014). They thank the owners of the herds chosen for this research and the administrative and technical staff in the farms for their invaluable cooperation in the field and also acknowledge the regionals cooperatives societies of livestock farmers (COLANTA, COLETRIUNFO, APAGRONAR (Asociación de Productores Agropecuarios de Puerto Nare), and COREGAN (Comite Regional de Ganaderos de Puerto Berrio)) because their important logistical support make it possible to execute the field work in this research. They want to also specially thank Carlos Adrian Lopera, project manager of Ecosphaira Colombia, for his valuable advice in the analyses of percent root colonization and spore density for this paper.

\section{References}

[1] M. Mofidi, M. Rashtbari, H. Abbaspour, A. Ebadi, E. Sheidai, and J. Motamedi, "Impact of grazing on chemical, physical and biological properties of soils in the mountain rangelands of Sahand, Iran," The Rangeland Journal, vol. 34, no. 3, pp. 297-303, 2012.

[2] S. Zubek, A. M. Stefanowicz, J. Błaszkowski, M. Niklińska, and K. Seidler-Łozykowska, "Arbuscular mycorrhizal fungi and soil microbial communities under contrasting fertilization of three medicinal plants," Applied Soil Ecology, vol. 59, pp. 106-115, 2012.

[3] R. S. Shange, R. O. Ankumah, A. M. Ibekwe, R. Zabawa, and S. E. Dowd, "Distinct soil bacterial communities revealed under a diversely managed agroecosystem," PLoS ONE, vol. 7, no. 7, Article ID e40338, 2012.

[4] N. L. Olivera, L. Prieto, M. B. Bertiller, and M. A. Ferrero, "Sheep grazing and soil bacterial diversity in shrublands of the Patagonian Monte, Argentina," Journal of Arid Environments, vol. 125, pp. 16-20, 2016.

[5] F. A. Holmann, L. Rivas, J. Carulla et al., "Evolución de los sistemas de producción de leche en el trópico latinoamericano y su interrelación con los mercados: un análisis del caso colombiano," CIAT, p. 53, 2003.

[6] V. E. Vallejo Quintero, "Importancia y utilidad de la evaluación de la calidad de suelos a través del componente microbiano: Experiencias en sistemas silvopastoriles," Colombia Forestal, vol. 16, no. 1, p. 83, 2013.

[7] Y. Jiménez, C. Martínez, and N. Mancera, "Caracteristicas fisicas y quimicas del suelo en diferentes sistemas de uso y manejo en el centro agropecuario Cotové, Santa Fe de Antioquia, Colombia," Suelos ecuatoriales, vol. 40, no. 2, pp. 176-188, 2010.

[8] R. Cañón-Cortázar, M. Avellaneda-Torres, and E. Torres-Rojas, "Associated microorganisms to the nitrogen cycle in soils under 
three systems of use: potato crop, livestock and páramo, in Los Nevados National Natural Park," Acta Agronómica, vol. 61, no. 4, pp. 339-347, 2012.

[9] V. E. Vallejo, Z. Arbeli, W. Terán, N. Lorenz, R. P. Dick, and F. Roldan, "Effect of land management and Prosopis juliflora (Sw.) DC trees on soil microbial community and enzymatic activities in intensive silvopastoral systems of Colombia," Agriculture, Ecosystems \& Environment, vol. 150, pp. 139-148, 2012.

[10] A. M. Cubillos, V. E. Vallejo, Z. Arbeli et al., "Effect of the conversion of conventional pasture to intensive silvopastoral systems on edaphic bacterial and ammonia oxidizer communities in Colombia," European Journal of Soil Biology, vol. 72, pp. 4250, 2016.

[11] Instituto Colombiano Agropecuario, Fertilización en diversos cultivos: quinta aproximación, Santa Fé de Bogotá, 5th edition, 1992.

[12] P. J. Wood, "Specificity in the interaction of direct dyes with polysaccharides," Carbohydrate Research, vol. 85, no. 2, pp. 271287, 1980.

[13] G. Pontecorvo, J. A. Roper, L. M. Chemmons, K. D. Macdonald, and A. W. J. Bufton, "The Genetics of Aspergillus nidulans," Advances in Genetics, vol. 5, no. C, pp. 141-238, 1953.

[14] G. Andrade, "Role of functional groups of microorganisms on the rhizosphere microcosm dynamics," Plant Surface Microbiology, pp. 51-69, 2008.

[15] L. Beltrán-Pineda and M. Lizarazo-Forero, "Grupos funcionales de microorganismos en suelos de páramo perturbados por incendios forestales," Revista de Ciências, vol. 17, no. 2, pp. 121136, 2013.

[16] S. Wilson and P. Knight, Experiments in bacterial physiology, Burguess, Publishing Co, Minneapolis. USA, 1952.

[17] J. Dobereiner and J. Day, "Associative symbiosis and free-living systems," in Proceedings of the 1st International symposium on Nitrogen fixation, W. E. Newton and C. J. Nyman, Eds., pp. 518538, Washington state University. Press. Pullman., 1976.

[18] E. Küster and S. T. Williams, "Selection of media for isolation of streptomycetes," Nature, vol. 202, pp. 928-929, 1964.

[19] J. M. Phillips and D. S. Hayman, "Improved procedure for clearing roots and staining parasitic and vesicular-arbuscular mycorrhizal fungi for rapid assessment of colonization," Fungal Biology, vol. 55, no. 1, pp. 158-161, 1970.

[20] Astm, "D4959 - Standard Test Method for Determination of Water (Moisture) Content of Soil By Direct Heating," Astm D4959, pp. 5-8, 2000.

[21] M. R. L. Garcia, A. A. M. Sampaio, and E. Nahas, "Impact of different grazing systems for bovine cattle on the soil microbiological and chemical characteristics," Revista Brasileira de Zootecnia, vol. 40, no. 7, pp. 1568-1575, 2011.

[22] H. Wang, J. Mo, X. Lu, J. Xue, J. Li, and Y. Fang, "Effects of elevated nitrogen deposition on soil microbial biomass carbon in major subtropical forests of southern China," Frontiers of Forestry in China, vol. 4, no. 1, pp. 21-27, 2009.

[23] S. A. Billings and S. E. Ziegler, "Altered patterns of soil carbon substrate usage and heterotrophic respiration in a pine forest with elevated CO2 and N fertilization," GCB Bioenergy, vol. 14, no. 5, pp. 1025-1036, 2008.

[24] K. K. Treseder and M. F. Allen, "Direct nitrogen and phosphorus limitation of arbuscular mycorrhizal fungi: a model and field test," New Phytologist, vol. 155, no. 3, pp. 507-515, 2002.

[25] B. F. T. Brockett, C. E. Prescott, and S. J. Grayston, "Soil moisture is the major factor influencing microbial community structure and enzyme activities across seven biogeoclimatic zones in Western Canada," Soil Biology \& Biochemistry, vol. 44, no. 1, pp. 9-20, 2012. 


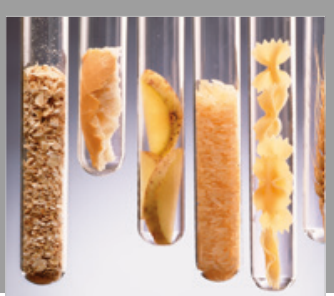

International Journal of Food Science

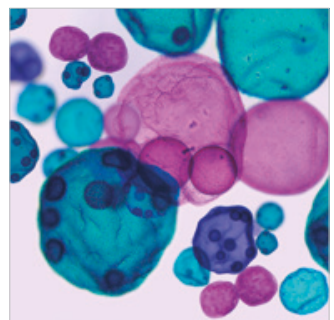

International Journal of Microbiology
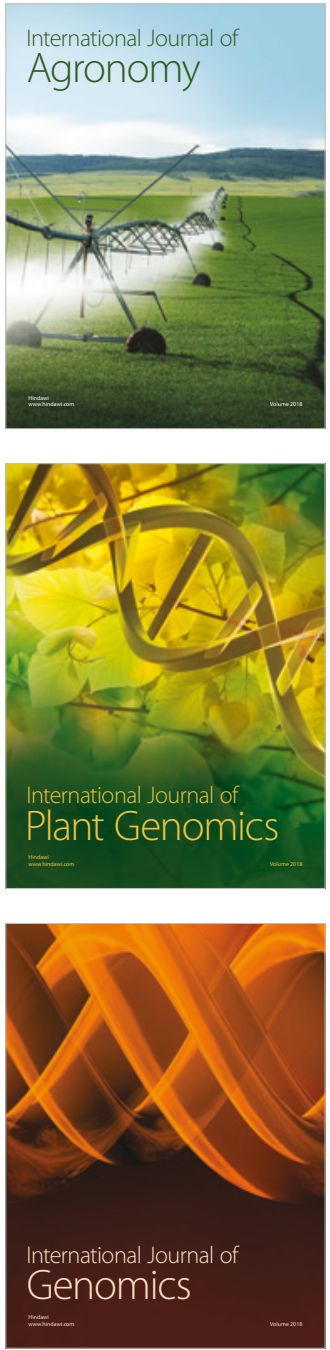

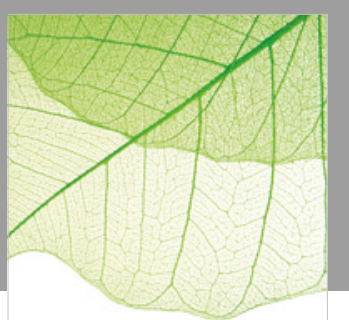

Journal of Botany
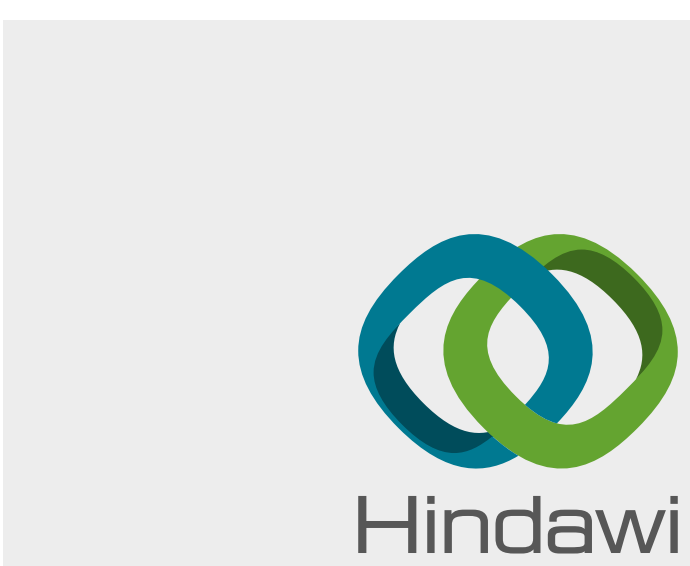

Submit your manuscripts at

www.hindawi.com
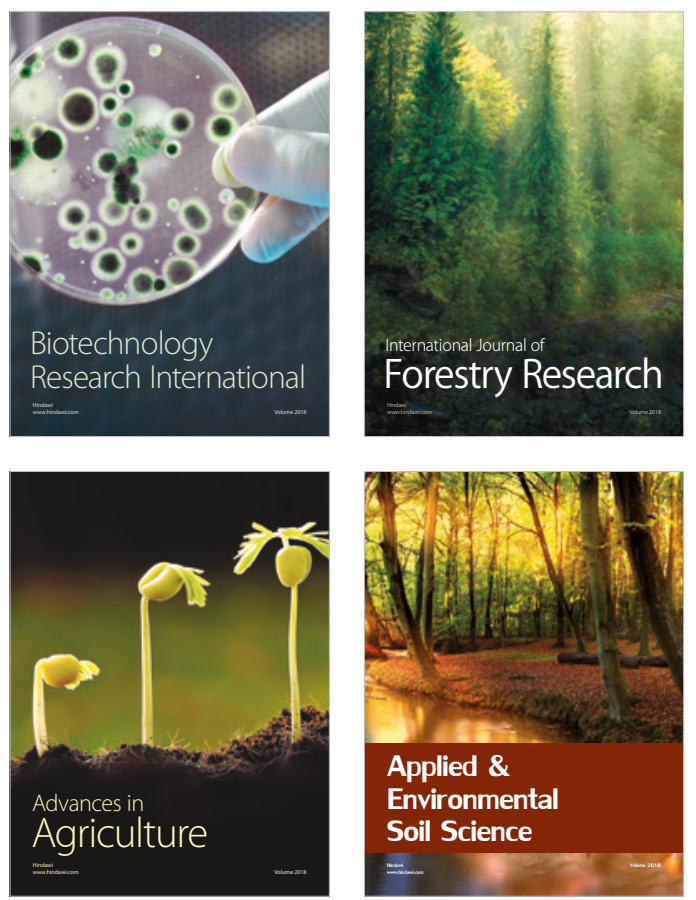

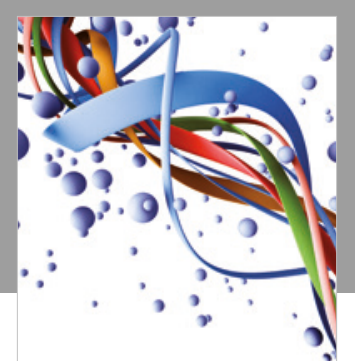

Scientifica

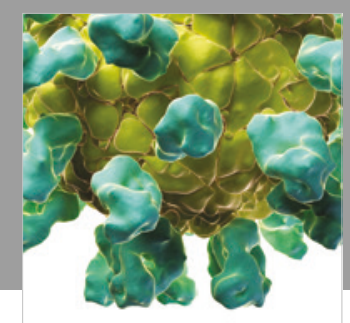

Veterinary Medicine International

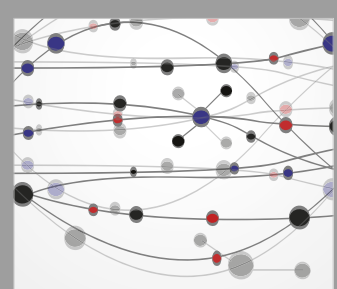

The Scientific World Journal
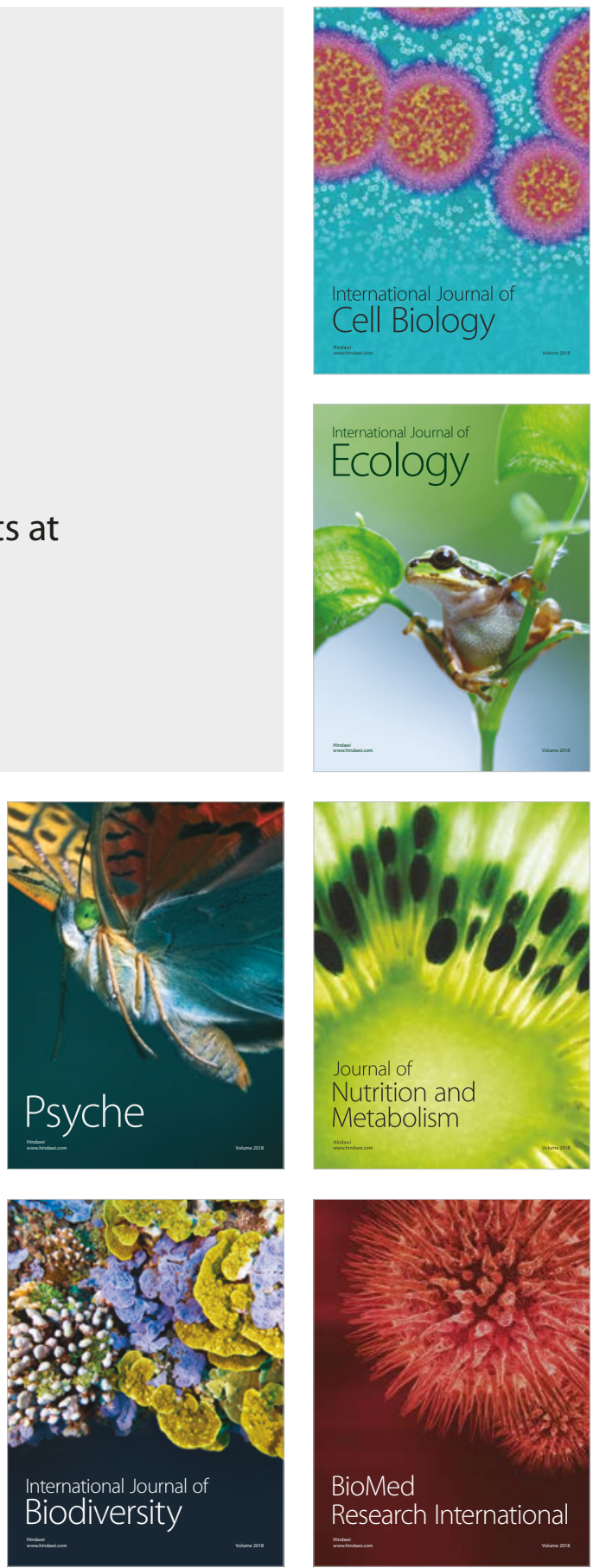